\title{
The role of state ownership and institutions in the innovation performance of emerging market enterprises: Evidence from China
}

\section{Abstract}

Although it has been suggested that institutional context influences a firm's innovation performance, the role of regulatory institutions has been underexplored. Extending previous research, this study investigates whether and how regulatory institutions (i.e. state ownership, region-specific marketization and industry-specific institutional policy) affect innovation performance of emerging market enterprises (EMEs). Evidence derived from a large sample of Chinese manufacturing firms demonstrates that state ownership positively moderates the effect of $R \& D$ intensity on innovation performance. However, state ownership is not equally beneficial for all firms. Our analysis shows that region-specific marketization and industry-specific institutional policy enhance the innovation-enhancing effect of state ownership. By revealing the role of regulatory institutions, our study points to the importance of looking beyond firm boundaries to understand why EMEs are able to innovate despite their weak internal capabilities.

Key words: State ownership, marketization, industry policy, emerging market enterprises, innovation performance

\section{Introduction}

This paper studies how institutional forces affect innovation of firms in emerging markets. Emerging market enterprises (EMEs) have significantly improved their technological capabilities in recent years and are increasingly relying on technological innovation to compete in the global marketplace (Wu et al., 2016; Yi et al., 2013). The Chinese company Huawei, for example, is ranked $17^{\text {th }}$ in the world in terms of the number of patents granted in 2013. Because these firms traditionally do not possess strong internal capabilities (Wang et al., 2012b, Hong et al., 2015), which according to the Schumpeterian view (Schumpeter, 1942) are critical for developing innovation, the emergence of Chinese EMEs as innovators raises the following question: what is the role of institutions in EMEs' innovation given that unlike their counterparts in developed countries these firms cannot generally rely 
on internal capabilities to innovate and also operate in weak regimes of intellectual property rights (IPRs) that often cannot effectively protect innovation? The theoretical significance of this research question derives largely from the importance of understanding the sources of competitive advantages that enable EMEs to develop innovation. In this study, we argue that regulatory institutions at the firm- (namely, state ownership), region- (namely, marketization) and industry- (namely, industry policy) levels compensate for the weak capabilities of EMEs, enabling them to enhance innovation performance.

Our study advances the literature on innovation in emerging markets in two ways. First, while prior studies have focused on the (direct) effect of state ownership on EMEs' innovation (e.g., Choi et al., 2011; Ren et al., 2005), it remains unclear how state ownership affects innovation performance by moderating the effect of R\&D intensity of the firm. It is both theoretically and empirically well established that a firm's internal R\&D has a positive effect on innovation performance (Schumpeter, 1942; Kafouros et al., 2008; Wang and Kafouros, 2009). It is also well recognized that government as a key shareholder in state owned enterprises (SOEs) plays an important role in developing innovative activities in emerging markets (Mahmood and Rufin, 2005). However, little is known about how state ownership and R\&D intensity interact to shape a firm's innovativeness in emerging markets., This research gap is significant because it limits our understanding of the mechanisms through which state ownership influences the relationship between $R \& D$ intensity and innovation performance. Viewing it as a firm level innovation-supporting institution (Cui and Jiang, 2012), we argue that state ownership acts as a moderating mechanism in the relationship between R\&D intensity and innovation performance. Our approach enables us to explain how internal capabilities and firm-specific institutional idiosyncrasies jointly shape the innovation outcomes of Chinese firms.

Second, previous studies in the subject area have ignored how institutional variations across subnational regions and industries influence the relationship between state ownership and innovation (e.g., Jefferson et al., 2006; Sun and Du, 2010). These studies often implicitly assume that the effect of state ownership on innovation remains similar across different subnational locations and industries within a given country (Li and Tellis, 2016; Yi et al., 2013; Wang et al., 2015b). Because large emerging countries such as China exhibits significant variations in institutional development across subnational regions (Kafouros et al., 2015) which constitute sources of different competitive advantages and 
institutional pressures on firms (Hermelo and Vassolo, 2010), it is essential not to merely focus on national level institutions and instead to examine the effect of region-level institutional context on firms' innovation performance. We address this lacuna in research and advance the premise that significant institutional variations across regions and industries within a given nation may have a profound impact on the effect of state ownership. Hence, rather than assuming that state ownership is equally beneficial for all firms, we propose that this effect varies depending on location- and industry-specific regulatory institutions, namely, the level of region-specific marketization and industry-specific policy.

Furthermore, although previous studies suggest that institutions influence the availability and cost of innovation inputs and appropriation of value from innovation (e.g., Lu et al., 2008), these studies have not focused on a specific type of institutions and under-theorize the role of regulatory institutions. Building upon prior literature, we specifically account for the effects of regulatory institutions (i.e. state ownership, region-specific institutions and industry-specific institutional policy) which are considered as a key discriminating factor of the success of innovation and entrepreneurial efforts (Mahmood and Rufin, 2005). We contend that, although it is often argued that emerging markets feature 'institutional voids' (Khanna and Palepu, 1997) that may constrain firms' innovative activities, the regulatory environment, particularly government-related institutions, provide distinctive potential for EMEs to pursue nonmarket-based strategies (Hermelo and Vassolo, 2010) and develop innovation.

Our arguments are tested on a sample of 193,506 Chinese firms during 2005-2007. The results indicate that state ownership positively moderates the effect of $R \& D$ intensity on innovation performance. Furthermore, region-specific marketization and industry-specific institutional policy enhance the effect of state ownership on innovation performance. These findings highlight the role of regulatory institutions in EMEs' innovation performance and thus provide a novel institution-based explanation for why many capability-constrained EMEs have grown in recent years as innovators.

\section{Theoretical framework and hypotheses}

\subsection{The effects of institutions on innovation}

It is well acknowledged that institutional context - defined as the environment that comprises social forms of the economic and political system, created and also used by various actors in a society (Turner 
2006; Fligstein 2001), influences firms' innovation performance (Mahmood \& Rufin, 2005; Wang et al., 2015). Institution theory suggests that a firm's strategy and behavior is the result of, or response to, a particular institutional context in which a firm is embedded (Alvi, 2012; Scott, 1995). Institutional context influences innovation by defining opportunities, by reducing the unknown, and by increasing or decreasing costs of economic exchanges (North, 1990). For example, institutional factors such as factor markets and protection of IPRs can influence the availability and cost of innovation inputs as well as the protection of innovation outputs (Wang et al., 2015).

Institutional context has three key dimensions - regulative, normative, and cognitive rules (Scott, 1995). While the role of these three types of institutions is often empirically indistinguishable (DiMaggio and Powell, 1983), it is important to focus on key institutional dimensions which influence the phenomena under study (Kostova and Roth, 2002). Despite market-oriented reforms, Chinese firms still operate in highly regulated environments characterized by high levels of state ownership and strong government institutions (Hong et al., 2015). We therefore focus our attention on the role of the regulatory pillar within which government related institutions and policy represent a strong institutional logic (Alford and Friedland, 1985) and constitute key institutional aspects governing business transactions (Whitley, 1999). In this study, we examine the role of state ownership, region-specific marketization and industry-specific institutional policy in EMEs' innovation performance. These three constructs are closely related to, or are manifestations of, government policy, regulations and laws, and are therefore important regulatory institutions in the light of Scott (1995). For example, because state owned enterprises (SOEs) are, by definition, assets of governments and state ownership is inextricably associated with government policy, regulations and laws, they are in fact integral elements of their country's regulatory environment (Cui and Jiang, 2012; Tõnurist, 2015).

State ownership influences innovation in two important ways. First, government as a shareholder of SOEs exerts various institutional pressures on firms that can influence the incentives and ability of firms to develop innovation. For example, the Chinese government formally introduced the policy of ‘indigenous innovation' as part of China's national strategy in 2005 (Bichler and Schmidkonz, 2012, p.2). Such regulatory pressures might be higher for SOEs than for other firms because these firms have a greater need to conform to institutional prescriptions (Baum and Oliver, 1991) and serve government 
objectives (Tõnurist, 2015; Wang et al., 2012b). Such institutional forces also influence firms' ability to develop innovation because firms that conform to such institutional pressures can enjoy a higher level of legitimacy and sociopolitical approval (Aldrich and Fiol, 1994). This in turn helps them create innovation by reducing regulatory uncertainty, securing scarce resources in the quasi-market economy and mitigate agency problems (Shleifer and Vishny, 1998). By contrast, because their relative lack of legitimacy and sociopolitical approval, non-state Chinese firms may be unable to obtain access or have to pay a market price for such resources, which hampers their innovation efforts.

Second, state ownership also affects firms' ability to appropriate value from innovation. Although IPR protection is critical element of the regulatory environment for innovation (Bouet, 2015; Zobel et al., 2017), its enforcement in emerging markets is weak and often depends on the status of the firm ( $\mathrm{Li}$ et al., 2004). State ownership may protect the firm in cases where IPR laws are weakly enforced. Because governments can provide exclusive endorsements and favorable treatment (Sheng et al., 2011), SOEs often receive stronger protection of IPRs (Wang et al., 2012b), enabling them to better appropriate the value of innovation. By contrast, although non-state firms such as private firms may have internal and other external mechanisms to address such agency problems, they suffer from discrimination and have difficulties in protecting and benefiting from their innovations.

Differences in innovation-supporting institutions exist not only between but also within countries (Nelson, 1993). Regions within China differ significantly in the extent to which government is involved in the coordination of economic actors (Hong et al., 2015). Hence, regulatory institutions vary across subnational regions of China. Similarly, the transitional nature of the Chinese economy presents considerable inter-industry variations of key institutional attributes such as government control and industry policy (Wang et al., 2009). These variations arise partly because the Chinese government often formulates industry-specific science and technology policies (Choi et al., 2011) and provides preferential support for the development of high-tech industries. These cross-region and industry differences imply that innovation performance is not only determined by firm-specific characteristics such as R\&D intensity and ownership but is also shaped by region- and industry-specific institutional idiosyncrasies. 
The institutional complementarity thesis suggests that "not only single institutions are subject to positive feedback effects, but configurations of complementary institutions in which the performance of each is affected by the existence of others" (Pierson, 2000:78). We propose that, in addition to the direct effects of institutions internal (i.e., state ownership) and external (i.e., region- and industryspecific institutions) to the firm on innovation performance, institutions at different levels also interact to jointly shape innovation outcomes. For example, differences in state ownership may also influence a firm's inclination and ability to respond to region- and industry-specific institutional pressures. Building on this reasoning, we argue that whereas state ownership may positively moderate the effects of $R \& D$ intensity on innovation performance, its effect on innovation performance will vary depending on region-specific marketization and industry-specific policy. Fig. 1 shows the framework of our study.

(Insert Fig. 1 about here)

\subsection{The moderating role of state ownership}

R\&D creates scientific knowledge (Griliches, 1979) that in turn helps firms develop new products or improve production efficiency and consequently enhances innovation performance (Lee et al., 2014; Wang and Kafouros, 2009). R\&D also enhances absorptive capacity by increasing a firm's ability to understand external ideas and technologies and to apply them to commercial ends (Cohen and Levinthal, 1989; Patterson and Ambrosini, 2015). Therefore, firms with higher R\&D intensity are more likely to achieve higher innovation performance. However, we argue that the effects of R\&D intensity on innovation performance may vary depending on the level of state ownership in the firm.

From an institutional perspective, state ownership signals a firm's adherence to institutional prescriptions of appropriate conduct that help to enhance legitimacy (Oliver, 1990). This in turn enables firms to get superior access to licenses, administrative privileges, and resources such as raw materials, low-cost capital and subsidies as well as information (Luo, 2003) unavailable from market channels. Such access also helps the firm secure unique technological resources and outputs of publicly-funded $R \& D$ and increases the variety and quality of $R \& D$ inputs and thus enhances the effect of $R \& D$ intensity. Innovation theory suggests that relying only on the recombination of the same set of internal knowledge can inhibit product innovation (Katila and Ahuja, 2002; Zobel et al., 2017). Ownership ties 
with government widen the scope of a firm's technology base, add both new and different elements to their R\&D resource base, generate synergies and complementarities between public R\&D and the firm's internal R\&D (Roper et al., 2008), and thus help them develop valuable and rare technological combinations.

Furthermore, state ownership also signals legitimacy to potential external partners (Hillman, 2005) and thus facilitates collaboration with these partners and knowledge acquisition (McKelvey et al., 2015). Technological collaboration with suppliers, for example, can enrich R\&D inputs by helping firms get access to information regarding developments in new technological processes (van Beers and Zand 2014), while collaboration with customers allows firms to understand their needs and to identify new direction of their R\&D efforts. Similarly, technological collaborations with foreign partners through strategic alliances act as important vehicles for knowledge acquisition (Kale and Singh, 2007), enabling SOEs to widen the scope of their technology base and enhance the quality of R\&D inputs and the effectiveness of R\&D efforts.

By contrast, because policy discrimination may prohibit obtaining important complementary resources to strengthen internal capabilities, a firm's internal R\&D is less likely to be positively associated with innovation performance when the level of state ownership is low. Therefore, even when two firms possess a similar level of R\&D intensity, they may differ in their ability to innovate due to differences in the level of state ownership in the two firms. Integrating these arguments, we propose the following:

Hypothesis 1: The higher the level of state ownership, the stronger the effects of R\&D intensity on Chinese firms' innovation performance.

\subsection{The role of region-specific marketization}

Government policy and regulations on market development are a key component of the regulatory environment of emerging markets. Because institutions depend on path-dependent and location-specific characteristics, the level of market development differs significantly across sub-national regions within 
a given country such as China (Yi et al., 2013). Regions with a higher degree of marketization are characterized by well-developed factor markets and innovation intermediaries and a strong protection of intellectual property rights (Aldrich and Fiol, 1994; Peng, 2003; Kafouros et al., 2015). By contrast, nonmarket influences and relationship-based exchanges are prevalent in underdeveloped markets (Peng, 2003; Wu, 2013), creating a greater risk of business uncertainty, unenforceable contract conditions and insecure property rights. Because diverse market contexts generate different competitive and institutional pressures on firms (Hermelo and Vassolo, 2010) that may influence the incentives and ability of EMEs to innovate, we argue that the effects of state ownership on innovation performance may vary across regions, depending on the degree of market development in the given location.

Two competing views exist regarding the role of government during institutional transition. Some argue that as market forces have started to prevail, the role of government in coordinating economic activities will decline. In such situations, firms are increasingly able to obtain critical resources from markets and non-governmental organizations such as business networks (Keister, 2009). By contrast, others contend that despite advancements in the marketization process, the government still plays an important role in countries such as China (Ruan et al., 2014) in part because 'political liberalization is usually not in line with economic liberalization' (Shi et al., 2014).

We argue that in well-developed markets, government remains an integral element of the economic system, but it plays a facilitating role by fostering market coordination that often fails at the developmental stage of the economy (Shi et al., 2012). In such regions, government attempts to foster innovation networks, thereby reducing the risks of innovation, and also collaborates on advanced R\&D and product development (Mahmood and Rufin, 2005), thus creating a favorable climate for SOEs to innovate. In such cases, market development and government involvement complement rather than substitute for one another to enhance innovation. By contrast, regions with insufficient market development feature institutional voids that hinder firms' ability to innovate.

Furthermore, the quality of governments tends to be higher in well-developed regions with a higher level of market development because economic development itself creates a demand for good government (North, 1981). Governments in such regions are more accountable, transparent and have better capabilities to deliver a bundle of interventions more effectively and efficiently, develop market 
monitoring mechanisms, foster innovation intermediaries, and protect innovation output against imitation. By contrast, government is less efficient in regions with underdeveloped markets. For example, Fan et al. (2007) find that it takes a much longer time to address various clearances and start a new business in China's regions with underdeveloped markets. Hence, even if two firms have a similar level of state ownership, we would expect better protection of IPRs by government in regions with a higher level of marketization than in regions with a lower level of marketization. This in turn enhances SOEs' ability to appropriate value from innovation. These arguments lead us to contend for a complementary rather than a substitution effect between state ownership and market development in regard to their impact on innovation performance. We therefore propose the following:

Hypothesis 2: The effects of state ownership on Chinese firms' innovation performance will be stronger in regions with a higher degree of marketization than in regions with a lower degree of marketization.

\subsection{The role of industry-specific institutional policy}

Industrial sectors are coordinated and governed by a unique configuration of regulatory arrangements (Hollingsworth, 2000). Industrial policy has diverse instruments such as provision of subsidies and tax incentives to support emerging and strategic sectors and companies to cope with market failures. Although governments in emerging markets often adopt a favorable attitude towards innovation, policy is often implemented at the industry level (i.e., it introduces sector-specific innovation incentives and regulations). In China, for example, innovation is encouraged and subsidized in some industries but is not a governmental priority in other sectors. We argue that such inter-industry institutional differences are an important source of variations that can shape the trajectory and outcomes of EMEs' innovative activities in different ways. We thus propose that industry-specific institutional policy moderates the relationship between state ownership and innovation performance.

First, government uses policy instruments to establish supportive conditions to facilitate firms' access to factors critical to innovation such as finance and opportunities for collaboration. For example, the Chinese government has introduced industrial policies that support the development of high-tech 
sectors in order to strengthen competitiveness, encourage investments in innovation, and promote hightech trade (Liu et al., 2011). As a result, the process of getting approval for large R\&D projects in these industries is likely to be easier and less time consuming. This may lead to synergistic effects between state ownership and institutional policy. Because of their state owned status, SOEs operating in these industries benefit disproportionately from policy initiatives that support innovation, in additional to those 'normal' benefits associated with state ownership. Furthermore, due to government support SOEs are resources-rich, which may help them respond successfully and proactively to institutional changes in innovation (Castrogiovanni, 1991), accelerate organizational learning, reengineer routines and thus be more capable of taking advantage of favorable policy initiatives (Wang et al., 2012b). The benefits that SOEs receive from a favorable policy can further create structural entry barriers (Mahmood and Mitchell, 2004), preventing other firms from investing in R\&D projects in the same industry. By contrast, in industries where governments do not specifically emphasize innovation, political interests and institutional policies on innovation are not always consistent with the innovation strategy of SOEs. This likely leads to conflicts between managers and government officials and alters the firm's innovation plans_-particularly for SOEs where direct government involvement is high.

Second, operating in policy-favored industries provides SOEs with additional amount of legitimacy and heightened levels of sociopolitical approval (Aldrich and Fiol, 1994). As discussed above, this in turn facilitates firms' acquisition of resources and technological collaborations with suppliers and customers and therefore enhances their innovation performance. Therefore, compared with their counterparts in other industries, SOEs in government-favored industries will have greater opportunities to find complementary and supplementary resources that help to generate unique technological combinations. Hence, although state ownership may enhance innovation performance, this effect will become even stronger in sectors where government has preferential policy to support innovation.

Hypothesis 3: The effects of state ownership on Chinese firms' innovation performance will be stronger in industries in which industry-specific institutional policy provides preferential support for innovation than in industries without such policy support. 


\section{Data and Methods}

\subsection{Sample}

Our study uses a firm-level panel dataset of the Chinese manufacturing firms for the period of 2005-2007. China offers an ideal setting for testing existing innovation theories and developing new ones because the co-existence of the socialist legacy and market institutions presents an institutional environment that is immensely different from that in the developed economies (Kornai, 1992; Peng, 2003). China has employed a dual-track approach to its market transition that liberalizes the former central planning system but retains government controls (Luo, 2007). As a result, the market and government-controlled governance mechanisms that coexist in the country influence innovation in ways that are not predicted by conventional theory. Furthermore, China has implemented an unbalanced reform strategy that allows local governments to prioritize their interests and support and protect their own firms (Boisot and Meyer, 2008). Similarly, China has adopted a technology catch-up model that is often implemented on an industry level. The Chinese government introduced industry-specific regulations and incentives for innovation in some industries but not in others. These policy initiatives, together with path-dependent factors, resulted in institutional differences across regions and industries within China, making the country an ideal context for this research.We obtained the data from the Annual Census of Chinese Industrial Firms complied by the National Bureau of Statistics of China (NBS). The Census is a comprehensive dataset that accounts for approximately $90 \%$ of the total output in most industries. It provides detailed firm-level information for all firms with an annual turnover of over five million Renminbi (around $\$ 680,000$ ). Different versions of this dataset have been used in previous studies (e.g., Liu et al., 2009; Hong et al., 2015; Wang et al., 2015b). We constructed our sample in several steps. First, we undertook extensive checks and cleaned the data for coding errors, including identifier code, industry code, and geographical code, missing values and outliers. Second, we removed observations for firms that are not in operation or are bankrupted, controlling for the effects of firm entry and exit dynamics. Finally, we checked for possible organizational changes, including mergers and acquisitions and ownership changes. Through the process we removed 195,096 out of the total of 388,602 firms, leaving us a final balanced dataset of 193,506 firms. 


\subsection{Measures}

\subsubsection{Dependent variable}

Our dependent variable is innovation performance, which is measured by the share of new product sales over total sales. New products are defined by the State Statistical Bureau of China as those goods that feature stronger functions or extended scope of usage, resulting from the adoption of new structures, designs or manufacturing techniques (Wang and Kafouros, 2009). New product sales include innovations that are not patented but are employed in the production process (Liu and Buck, 2007) and are commonly thought to be a good indicator of market acceptance of a new product (Atuahene-Gima and $\mathrm{Li}, 2004)$. By contrast, patent-based measures often do not reflect the economic value of these innovations, and not all innovations are patentable (Wang et al., 2015). Therefore, this measure is widely used in the innovation literature (Liu and Buck, 2007; Roper and Arvanitis, 2012; Wang et al., 2015b).

\subsubsection{Independent variable}

$R \& D$ intensity is measured as the ratio of $R \& D$ expenditure to total sales (Lee and O'Neill, 2003; Zhang et al., 2007). We measure state ownership by the share of state-owned assets to total assets (Wang et al., 2012a). We operationalize region-specific marketization using the marketization index developed by Fan et al. (2010) for 2005-2007. The marketization index of Fan et al. (2010) is a comprehensive composite index that evaluates the development of market-based mechanisms in each of China's regions in five key areas including the role of market relative to government, the development of the private sector, the development of commodity and factor markets, and the development of free market institutions by a total of twenty-six indicators. A greater score indicates a higher level of marketization within a region. This index is widely used by scholars (e.g., Hong et al., 2015; Yi et al., 2013). Finally, we include industry-specific institutional policy, which is a dummy variable that is coded 1 if the firm operates in an industry where industrial policy is favorable to innovation and 0 otherwise. According to the National Bureau of Statistics of China (NBS), the industries for which Chinese government provides preferential policies to support innovation include Petroleum refining and coking, Raw chemical materials and chemical Products, Medical and pharmaceutical products, Special purposes equipment, 
Transport equipment, Telecommunications, Computer and other electronics, Instruments and meters. Firms in these industries can get special funds, grants, cheap credits and tax incentives from government or state-owned banks to support their innovative activities such as establishment of incubators and technological collaboration with foreign firms.

\subsubsection{Control variables.}

First, we include firm size, measured by the natural logarithm of total number of employees. Second, firm age is measured by the number of years since the firm was founded. Third, human resources are operationalized using each firm's training expenditure per employee. Fourth, total factor productivity captures the firm's capability to produce more output from the same amount of inputs (Wang et al., 2012b) and is measured at the firm level within each 2-digit industry via a semi-parametric estimation technique (Levinsohn and Petrin, 2003). Fifth, we include foreign ownership, which is measured as the ratio of assets owned by foreign investors to total assets in a firm. Sixth, export-oriented firms may react to high competition in the export markets by engaging in innovation intensively. We control such effects by export intensity, measured by the share of export sales to total sales. Seventh, because firms may invest more in R\&D through leverage, we control for this effect by leverage, measured by the ratio of total debts to total assets. Eighth, business group is concluded to control for network effects using a dummy that equals to 1 for firms affiliated with a business group and 0 otherwise. Ninth, industry competition is defined as one minus the average Lerner's index of individual firms in the 2-digit industry. The Lerner's index identifies the "degree of monopoly" with the difference between the firm's price and its marginal cost at the profit-maximizing rate of output (Aghion et al., 2005). Finally, we introduce some additional dummies to account for idiosyncrasies associated with industry, region, and time variations. Table 1 summarizes the variables and their expected effects on innovation performance.

\section{(Insert Table 1 about here)}

\subsection{Estimation method}

To test our hypotheses, we employed hierarchical moderated regression analyses with Tobit specification (Wooldridge, 2002). Tobit regression is appropriate when the dependent variable is limited 
or censored (Tobin, 1958), which is standard practice in innovation studies that use a similar dependent variable (e.g., Berchicci, 2013). Because Models with interaction terms are sensitive to multicollinearity and heteroskedasticity issues, we followed the usual practice (Aiken and West, 1991) and we meancentered the firm-specific variables and moderators before creating the interaction terms to avoid problems of multicollinearity between the interaction term and its constituent parts. In addition, we lagged all independent variables and interactions by one year, given that our sample spans only three years. The lag structure allows us to account for the fact that some of these effects take some time to materialize. It also helps to reduce the concern for endogeneity concerns and simultaneity bias (Aitken and Harrison, 1999). Finally, we used Huber-White's robust standard error to deal for the possible threat of heteroscedasticity (White, 1980).

\section{Results}

Before testing our hypotheses, we examined the descriptive statistics of our variables. Table 2 shows the means, standard deviations, and correlations for all the variables. We inspected the variance inflation factors (VIFs) of the variables. The VIFs range from 1.00 to 1.38 , and the average value is well below the acceptable level of 10 (Neter et al., 1985), indicating that multicollinearity did not have an undue influence on the estimates.

\section{(Insert Table 2 about here)}

Table 3 presents the results for hypotheses pertaining to interaction effects (H1-H3). Model 1 serves as the baseline model because it includes control variables only. Four independent variables including R\&D intensity, state ownership, region-specific institutions and industry-specific policy are added to Model 2. All three institutional variables (state ownership, region-specific institutions and industry-specific policy) are highly statistically significant, highlighting the importance of institutional factors for innovation performance in emerging markets. The coefficient of the state ownership variable suggests that a $1 \%$ increase in the ratio of state owned assets to total assets leads to an increase of $0.094 \%$ in the share of new product sales to total sales. Models 3-5 present the results for the hypotheses pertaining to the contingency approach $(\mathrm{H} 1-\mathrm{H} 3)$. The interaction term in Model 3 is positive and statistically significant, supporting H1. This finding suggests that state ownership enhances the effects 
of R\&D intensity on innovation performance. Similarly, both interaction terms in Models 4 and 5 are positive and significant, corroborating Hypotheses 2 and 3, respectively. These results indicate that although state ownership is positively associated with innovation performance, such effect is contingent upon industry- and location-specific idiosyncrasies including the market development of each region and the institutional policy within a given industry. To better explain the moderating effects of government involvement, these relationships are presented in Fig. 2.

(Insert Table 3 about here)

(Insert Fig. 2 about here)

\section{Robustness checks}

We conducted several sensitivity analyses to ensure the robustness of our results. First, we included a full model including all independent variables and interaction terms in Model 6 of Table 3. The results remain qualitatively unchanged except the interaction term between state ownership and marketization, which is now statistically insignificant at the $5 \%$ level. Second, we used state ownership dummy as an alternative measure (i.e., one for state owned shares above 0.5 and zero otherwise), and the use of this new measure does not produce qualitatively different results. Third, despite the problems of linearity assumptions applied in censored dependent variables, we estimated the regressions with an OLS estimator. The results (Table 4) are similar to our based case.

(Insert Table 4 about here)

Third, state ownership may be influenced by innovation performance, raising the concern of endogeneity. The problem likely arises because in the process of economic reform and privatization, the Chinese government tends to retain control over more innovative and productive state owned enterprises. We took several measures to control for endogeneity. We first reduced concerns about endogeneity arising from omitted variables by including several firm-level covariates as controls for other important firm characteristics. In addition, we used lagged independent variables to reduce the potential endogeneity bias, if any. We also followed Xia et al. (2014) and further alleviated this concern by turning the dependent variable innovation performance into an independent variable and regressed state ownership on innovation performance. The coefficient of innovation performance was not significant in the robustness test, suggesting that reverse causality is unlikely to occur in our sample. 
Furthermore, we employed an efficient instrumental variables estimator via the two-step GMM approach to tackle the problem. The method takes into account econometric problems that arise when estimating the model with endogenous variables, heterogeneity and autocorrelation (Caldera, 2010). Following Lee and O'Neil (2003), we chose firm age and firm size as instruments (rather than controls). In order to assess the appropriateness of the instrument variable method in terms of instrument relevance and exogeneity conditions (Bascle, 2008), we performed two diagnostic tests. First, the Durbin-Wu-Hausman test rejects the null hypothesis that the instrument is not necessary at the $1 \%$ significance level (Rawley, 2010). Second, the Sargan test does not reject the null hypothesis that the instruments are uncorrelated with the error term in all specifications (Bascle, 2008). Moreover, we conducted instrument redundancy test to ensure that both instruments are appropriate. The results confirm our choice. Table 4 shows that all key results from the two-step GMM instrumental variables estimator remain qualitatively unchanged.

\section{Discussion}

\section{Implications for theory}

First, the results show that state ownership enhances the effect of R\&D intensity on innovation performance. Interestingly, we show that R\&D intensity enhances innovation performance when the level of state ownership in the firm is high (the coefficient of the interaction term between R\&D intensity and state ownership is larger than the coefficient of the R\&D intensity on its own in Model 3). This finding is in line with previous studies (Wang et al., 2015a; Kafouros et al., 2015) that underscore the role of government involvement in Chinese firms' innovation performance. State ownership confers legitimacy that helps the firm secure critical resources unavailable from market channels, thus enhancing innovation performance. Our finding challenges the conventional approach that often implicitly assumes a monotonous relationship between R\&D intensity and innovation performance and instead suggests that $R \& D$ intensity has a stronger effect in some situations but not in others. An implication of this finding for theory is that future predictions about the effects of R\&D intensity should be linked to the degree of state ownership in the firm (when there is). This finding also enriches literature 
on the role of institutions in innovation by identifying and documenting how regulatory rules and regulations influence innovation of EMEs.

Second, our findings show that the effect of state ownership on innovation performance is stronger in regions with a higher level of marketization than in regions with a lower level of marketization. The implication is that a firm's ability to take advantage of state ownership to enhance innovation is conditioned by the regulatory idiosyncrasies of each region. Prior research focuses largely on the positive or negative effect of state ownership on innovation performance (e.g., Choi et al., 2011) and fails to conceptualize the role of institutional context. Our study complements this line of research by shifting the focus from the direct nexus between state ownership and innovation performance to the moderating role of regional level institutions. This approach helps us understand the reasons for the inconclusive findings of previous studies. Prior thinking conceptualizes government involvement as a response to market imperfections or less munificent institutional conditions in emerging markets (e.g., Wang et al., 2012), implying that the role of government will diminish as markets evolve. However, our findings suggest a complementary effect between government involvement (state ownership) and market development. By demonstrating importance of capturing intra-national institutional diversity, our study contributes to a broader understanding of the differential role of state ownership in different institutional settings.

Third, we find that the role of state ownership is stronger in industries in which innovation is a strategic priority for the state than in other industries. Conventional innovation research has long been dominated by the industrial organization theory, which suggests that industry structure explains firm innovation. For example, studies have investigated the effects of an industry's technological level on a firm's innovation performance (Aghion et al., 2009). This stream of research, however, has largely neglected the role of industry-specific regulatory policy, thereby limiting understanding of how firmand industry-level institutions co-evolve and interact and how this shapes innovation outcomes in different industries (Hollingsworth, 2000). Our findings suggest that a sound industry-specific policy remains important for stimulating innovation in economies at an early stage of technological evolution (Mahmood and Rufin, 2005). By demonstrating how the role of state ownership is contingent on 
industry-specific regulatory policy, our study extends the literature that has largely focused on the direct effect of state ownership on innovation (e.g., Choi et al., 2011; Ren et al., 2005). It also helps to explain why firms in some industries become more innovative and why a particular industry in a specific country may excel (North, 1981, 1990).

Taken together, our findings extend prior scholarly work on innovation by emphasizing the advantages that originate from the regulatory environment as opposed to the role of capabilities that firms develop within their own boundaries. While previous studies often focus on country-level institutions, our attention on region-specific and industry-specific regulatory institutions complements and advances prior research on institutions and innovation by showing the industry and subnational region to be key units of analysis for the determinants of innovation performance in large emerging economies such as China. The institutional context in emerging markets such as China can actually act as architectures that provide the contours and framework within which actors interact to facilitate innovation (Teece, 1986). This view contrasts to prior thinking that largely sees the regulatory forces in emerging markets as hindrance to innovation. By conceptualizing regulatory forces as endogenously determined factors, government related institutions emerge as integral components of the innovation business model of emerging market firms. This view complements explanations of innovation that rely on internal $\mathrm{R} \& \mathrm{D}$ capabilities by showing that an important source of variation is the regulatory environment - which has been under-theorized in the innovation literature. Hence, our findings have theoretical implications regarding how an organizational field should be defined and how firms succeed in innovation by exploiting region- and industry-specific institutional advantages. In showing that the innovation of EMEs is institutionally embedded and requires a combination of a complementary set of institutional factors at different levels, the evidence points to the importance of looking beyond firm boundaries to understand the drivers of innovation in emerging markets.

\section{Implications for practice}

Our findings offer guidelines for how firms in emerging markets should develop strategy to enhance innovation performance. The study indicates that in emerging economies such as China, where market-based mechanisms are underdeveloped, government involvement and institutions play a salient 
role in enhancing innovation performance. Although the development of distinctive internal advantages is difficult, state ownership and institutions compensate for weak internal resources and capabilities. Therefore, one inescapable implication of this research is that, instead of simply viewing regulatory context as an exogenous element, firms can strategically exploit institutional advantages by carefully incorporating political and institutional factors into their innovation business models. Therefore, managers may exploit institutional environment in a way that reinforces their internal capabilities and helps them overcome various factors that impede innovation performance.

Our study shows that government-related advantages are context-specific, depending on industryand region-specific regulatory institutions. This suggests that managers need to consider a portfolio of institutional factors, paying particular attention to their interactions and complementarities. Because our view focuses on external relationships and power, it differs from traditional prescriptions that emphasize the development of internal R\&D capabilities. However, this does not imply that managers should rely only on advantages derived from their institutional context and pay less attention to the development of firm-specific capabilities. In fact, the benefits associated with regulatory institutions may lead to further reliance on external institutions and reduce the firm's motivation to become technologically competitive by developing internal capabilities.

\section{Conclusion}

We seek to examine whether and how regulatory forces influence innovation performance of firms in emerging markets. By treating the institutional element as an endogenous factor, state ownership emerges as an integral component of the innovation business models of the EME. Our findings show that although state ownership positively moderates the effect of $R \& D$ intensity on innovation performance, it is not equally beneficial to all EMEs. Our contingency analysis shows that regionspecific marketization and industry-specific institutional policy strengthen the innovation-enhancing effect of state ownership. These findings demonstrate the critical role of regulatory institutional forces in helping EMEs innovate despite their weak internal capabilities.

Despite the strength of the research design, our study has several limitations, some of which point to additional fruitful research. First, our measure of innovation performance is based on new product 
sales which do not allow us to assess the product's level of innovativeness (e.g., incremental vs radical innovation). Therefore, we cannot determine the effect of state ownership and institutions on the products' degree of innovativeness. Second, the use of a sample of Chinese firms gives rise to concerns about the applicability of our findings to other emerging countries. Because the degree of government involvement through state ownership and region- and industry-specific regulatory idiosyncrasies that form the basis of our framework may differ in other emerging countries, future studies based on other economies will contribute to generalizing the findings of this study. Third, our research uses second data which give us less control over what is researched within the topic. Future research can complements such secondary data research with primary data which allow researchers to pick up areas of interest and control the timelines. Finally, our study has examined the firm-, industry- and regionspecific institutional effects and their interactions. One interesting extension of the study would be to examine the relative importance of different external (industrial and regional) institutions for innovation performance.

\section{References}

Aghion, P, Bloom, N, Blundell, R, Griffith, R, Howitt, P., 2005. Competition and innovation: An inverted-U relationship. The Quarterly Journal of Economics 120 (2), 701-728.

Aghion, P., Blundell, R., Griffith, R., Howitt, P., Prantl, S., 2009. The effects of entry on incumbent innovation and productivity. Review of Economics and Statistics 91(1), 20-32.

Aiken, L., West, S., 1991. Multiple Regression: Testing and Interpreting Interactions. Sage Publications, Newbury Park, CA.

Aitken, B. J., Harrison, A. E., 1999. Do domestic firms benefit from direct foreign investment? Evidence from Venezuela. American Economic Review 89(3), 605-618.

Aldrich, H.E., and Fiol, C.M. 1994. Fools rush in? The institutional context of industry creation. Academy of Management Review 19 (4), 645-70.

Alford, R. R., Friedland, R. 1985. Powers of Theory: Capitalism, the State, and Democracy. Cambridge: Cambridge University Press. 
Alvi, F.H. 2012. Rethinking the institutional contexts of emerging markets through metaphor analysis. Management International Review 52 (4), 519-39.

Atuahene-Gima, K., Li, H., 2004. Strategic decision comprehensiveness and new product outcomes in new technology ventures. Academy of Management Journal 47(4), 583-597.

Bascle, G., 2008. Controlling for endogeneity with instrumental variables in strategic management research. Strategic Organization 6(3), 285-327.

Baum, J.A.C., Oliver, C. 1991. Institutional linkages and organizational mortality, Administrative Science Quarterly 36(3),187-218.

Berchicci, L., 2013. Towards an open R\&D system: Internal R\&D investment, external knowledge acquisition and innovative performance. Research Policy 42(1), 117-127.

Bichler, J. and Schmidkonz, C., 2012. The Chinese Indigenous Innovation System and its Impact on Foreign Enterprises. Munich Business School Working Paper, 2012-01.

Boisot, M., Meyer, M. W., 2008. Which way through the open door? Reflections on the internationalization of Chinese firms. Management \& Organization Review 4(3), 349-365.

Bouet, D., 2015. A study of intellectual property protection policies and innovation in the Indian pharmaceutical industry and beyond. Technovation, 38: 31-41.

Caldera, A., 2010. Innovation and exporting: Evidence from Spanish manufacturing firms. Review of World Economics 146 (4), 657-689.

Castrogiovanni, G. J., 1991. Environmental munificence: A theoretical assessment. Academy of Management Review 16(3), 542-565.

Choi, S. B., Lee, S. H., Williams, C., 2011. Ownership and firm innovation in a transition economy: Evidence from China. Research Policy 40(3), 441-452.

Cohen, W. M., Levinthal, D. A., 1989. Innovation and learning: The two faces of R\&D. Economic Journal 99(397), 569-596.

Cui, L., Jiang, F., 2012. State ownership effect on firms' FDI ownership decisions under institutional pressure: A study of Chinese outward-investing firms. Journal of International Business Studies 43(3), 264-284. 
DiMaggio, P. J., Powell, W. W. 1983. The iron cage revisited: Institutional isomorphism and collective rationality in organization fields. American Sociological Review 48(2), 147-160.

Fan, G., Wang, X. L., Zhu, H. P., 2007. Marketization Index in China: The Regional Process Report of 2006. Economic Science Press, Beijing.

Fan, G., Wang, X. L., Zhu, H. P., 2010. NERI Index of Marketization of China's Provinces 2009 Report. Economic Science Press, Beijing.

Fligstein, N. 2001. The architecture of markets: An economic sociology of twenty-first-century capitalist societies. Princeton: Princeton University Press.

Griliches, Z., 1979. Issues in assessing the contribution of R\&D to productivity growth. Bell Journal of Economics 10(1), 92-116.

Hermelo, F. D., \& Vassolo, R. 2010. Institutional development and hypercompetition in emerging economies. Strategic Management Journal 31(13), 1457- 1473.

Hollingsworth, J. R., 2000. Doing institutional analysis: Implications for the study of innovations. Review of International Political Economy 7(4), 595-644.

Hong, J., Wang, C., Kafouros, M., 2015. The role of the state in explaining the internationalization of emerging market enterprises. British Journal of Management 26(1), 45-62.

Jefferson, G. H., Bai, H., Guan, X., Yu, X., 2006. R\&D Performance in Chinese industry. Economics of Innovation \& New Technology 15(4/5), 345-366.

Kafouros, M., Buckley, P., Sharp, A., Wang, C., 2008. The role of internationalization in explaining innovation performance. Technovation 15(3), 233-251.

Kafouros, M. I., Wang, C., Piperopoulos, P., Zhang, M., 2015. Academic collaborations and firm innovation performance in China: The role of region-specific institutions. Research Policy 44(3), 803-817.

Kale, P. and Singh, H. 2007. Building firm capabilities through learning: The role of the alliance learning process in alliance capability and firm-level alliance success. Strategic Management Journal 28, 981-1000.

Katila, R., Ahuja, G., 2002. Something old, something new: A longitudinal study of search behaviour and new product introduction. Academy of Management Journal 45(6), 1183-1194. 
Keister, L. A., 2009. Organizational research on market transition: A sociological approach. Asia Pacific Journal of Management 26(4), 719-742.

Khanna, T., Palepu, K., 1997. Why focused strategies may be wrong for emerging markets. Harvard Business Review 75(4), 41-51.

Kornai, J., 1992. The Socialist System: The Political Economy of Communism. Oxford University Press, Oxford.

Kostova, T., Roth, K. 2002. Adoption of an organizational practice by subsidiaries of multinational corporations: institutional and relational effects. Academy of Management Journal 45(1), 215-233.

Laursen, K., Salter, A., 2006. Open for innovation: the role of openness in explaining innovation performance among UK manufacturing firms. Strategic Management Journal 27 (2), 131-150.

Lee, P. M., O’neil, H. M., 2003. Ownership structures and R\&D investments of U.S. and Japanese firms: Agency and stewardship perspectives. Academy of Management Journal 46(2), 212-225.

Lee, C. Y., Wu, H. L., Pao, H. W., 2014. How does R\&D intensity influence firm explorativeness? Evidence of R\&D active firms in four advanced countries. Technovation, 34: 582-593.

Levinsohn, J., Petrin, A., 2003. Estimating production functions using inputs to control for unobservables. Review of Economic Studies 70(2), 317-341.

Li, S., Park, S. H., Li, S., 2004. The great leap forward: The transition from relation-based governance to rule-based governance. Organizational Dynamics 33(1), 63-78.

Li, Y., Tellis, G. J., 2016. Is China uniform? Intra-country differences in the takeoff of new products. Technovation 47(1), 1-13.

Lin, Y. J., Fang, C., Zhou, L., 1998. Competition, policy burdens, and state-owned enterprise reform. American Economic Review 88(2), 422-427.

Liu, F., Simon, D., Sun, Y., Cao, C., 2011. China's innovation policies: Evolution, institutional structure, and trajectory. Research Policy 40(7), 917-931.

Liu, X., Buck, T., 2007. Innovation performance and channels for international technology spillovers: Evidence from Chinese high-tech industries. Research Policy 36(3), 355-366.

Lu, Y., Tsang, E. W., Peng, M. W., 2008. Knowledge management and innovation strategy in the Asia Pacific: Toward an institution-based view. Asia Pacific Journal of Management 25(3), 361-374. 
Luo, Y., 2003. Industrial dynamics and managerial networking in an emerging market: The case of China. Strategic Management Journal 24(13), 1315-1327.

Luo, Y., 2007. Are joint venture partners more opportunistic in a more volatile environment? Strategic Management Journal 28(1), 39-60.

Mahmood, I. P., Rufin, C., 2005. Government's dilemma: The institutional framework for imitation and innovation. Academy of Management Review 30 (2), 338-360.

Mahmood, I. P., Mitchell, W., 2004. Two faces: Effects of business groups on innovation in emerging economies. Management Science 50(10), 1348-1365.

McKelvey, M., Zaring, O., Ljungberg, D., 2015. Creating innovative opportunities through research collaboration: An evolutionary framework and empirical illustration in engineering. Technovation 39-40: 26-36.

Nelson, R. R., 1993. National systems of innovation: A comparative study. Oxford University Press, Oxford.

Neter, J., Wasserman, W., Kutner, M. H., 1985. Applied Linear Statistical Models. Irwin, Homewood, IL.

North, D., 1981. Growth and Structural Change. W.W. Norton, New York.

North, D., 1990. Institutions, Institutional Change and Economic Performance. Cambridge University Press, Cambridge, MA.

Oliver, C., 1990. Determinants of inter-organizational relationships: Integration and future directions. Academy of Management Review 15(2), 241-265.

Patterson, W., Ambrosini, V., 2015. Configuring absorptive capacity as a key process for research intensive firms. Technovation, 36-37: 77-89.

Peng, M. W., 2003. Institutional transitions and strategic choices. Academy of Management Review 28(2), 275-296.

Pierson, P., 2000. Not just what, but when: timing and sequence in political processes. Studies in American Political Development 14(1), 72-92. 
Rawley, E., 2010. Diversification, coordination costs, and organizational rigidity: Evidence from microdata. Strategic Management Journal 31(8), 873-891.

Ren, L., Krabbendam, K., Weerd-Nederhof, P. D., 2005. Innovation practices success in China: The use of innovation mechanisms in Chinese SOEs. Journal of Technology Management in China $1(1), 76-91$.

Roper, S., Du, J., Love, J. H., 2008. Modelling the innovation value chain. Research Policy 37(6), 961977.

Roper S., Arvanitis, S. 2012. From knowledge to added value: a comparative, panel-data analysis of the innovation value chain in Irish and Swiss manufacturing firms. Research Policy 41(6), 1093-1106.

Ruan, Y., Hang, C. C., Wang, Y. M., 2014. Government's role in disruptive innovation and industry emergence: The case of the electric bike in China. Technovation, 34(12): 785-796.

Schumpeter, J. A., 1942. Capitalism, Socialism and Democracy. Harper and Row, New York.

Scott, W. R. 1995. Institutions and organizations. Thousand Oaks, CA: Sage.

Sheng, S., Zhou, K., Li, J., 2011. The effects of business and political ties on firm performance: Evidence from China. Journal of Marketing 75(1), 1-15.

Shi, W., Markóczy, L., Stan, C., 2014. The continuing importance of political ties in China. Academy of Management Perspectives 28(1), 57-75.

Shi, W. S., Sun, S. L., Peng, M. W., 2012. Subnational institutional contingencies, network positions, and IJV partner selection. Journal of Management Studies 49(7), 1221-1245.

Shleifer, A., Vishny, R. W., 1998. The grabbing hand: Government pathologies and their cures. American Economic Association Papers \& Proceedings 87(2), 354-358.

Sun, Y., Du, D., 2010. Determinants of industrial innovation in China: Evidence from its recent economic census. Technovation 30 (9-10), 540-550.

Teece, D. 1986. Profiting from Technological Innovation: Implications for Integration, Collaboration, Licensing and Public Policy. Research Policy 15(6), 285-305.

Tobin, J., 1958. Estimation of relationships for limited dependent variables. Econometrica 26(1), 2436. 
Tõnurist, P., 2015. Framework for analyzing the role of state owned enterprises in innovation policy management: The case of energy technologies and Eesti Energia. Technovation, 38: $1-14$.

Turner, B. 2006. The Cambridge dictionary of sociology. Cambridge: Cambridge University Press.

van Beers C., Zand, F. 2014. R\&D Cooperation, Partner Diversity, and Innovation Performance: An Empirical Analysis. Journal of Product Innovation Management 31(2), 292-312.

Wang, C., Clegg, J., Kafouros, M., 2009. Country-of-origin effects of foreign direct investment: An industry level analysis. Management International Review 49(2), 179-198.

Wang, C., Hong, J., Kafouros, M., Boateng, A., 2012a. What drives outward FDI of Chinese firms? Testing the explanatory power of three theoretical frameworks. International Business Review 21(3), 425-438.

Wang, C., Hong, J., Kafouros, M., Wright, M., 2012b. Exploring the role of government involvement in outward direct investment from emerging economies. Journal of International Business Studies 43(7), 655-676.

Wang, C., Hong, J., Kafouros, M., 2015a. The role of the state in explaining the internationalization of emerging market enterprises. British Journal of Management, 26 (1), 45-62.

Wang, C., Kafouros, M., 2009. What factors determine innovation performance in emerging economies? Evidence from China. International Business Review 18(6), 606-616.

Wang, C., Yi, J., Kafouros, M., Yan, Y., 2015b. Under what institutional conditions do business groups enhance innovation performance? Journal of Business Research 68(3), 694-702.

White, H., 1980. A heteroscedasticity consistent covariance matrix estimator and a direct test for heteroscedasticity. Econometrica 48(4), 817-838.

Whitley, R. 1999. Divergent capitalisms: The social structuring and change of business systems. Oxford: Oxford University Press.

Wooldridge, J., 2002. Econometric Analysis of Cross Section and Panel Data. MIT press, Cambridge. Wu, J., 2013. Diverse institutional environments and product innovation of emerging market firms. Management International Review 60(4), 493-518. 
Wu, J., Wang, C., Piperopoulos, P., Zhou, B., 2016. Internationalization and innovation performance of emerging market enterprises: The role of host-country institutional development. Journal of World Business 51 (2): 251-263.

Xia, J., Ma, X., Lu, J.W., Yiu, D. W., 2014. Outward foreign direct investment by emerging market firms: A resource dependence logic. Strategic Management Journal 35(9), 1343-1363.

Yi, J., Wang, C., Kafouros, M., 2013. The effects of innovative capabilities on exporting: Do institutional forces matter? International Business Review 22(2), 392-406.

Zhang, Y., Li, H., Hitt, M. A., Cui, G., 2007. R\&D intensity and international joint venture performance in an emerging market: Moderating effects of market focus and ownership structure. Journal of International Business Studies 38(6), 944-960.

Zobel, A. K. Lokshin, B. and Hagedoorn, J. (2016). Formal and informal appropriation mechanisms: The role of openness and innovativeness. Technovation, 59: 44-54. 
Figures and Tables

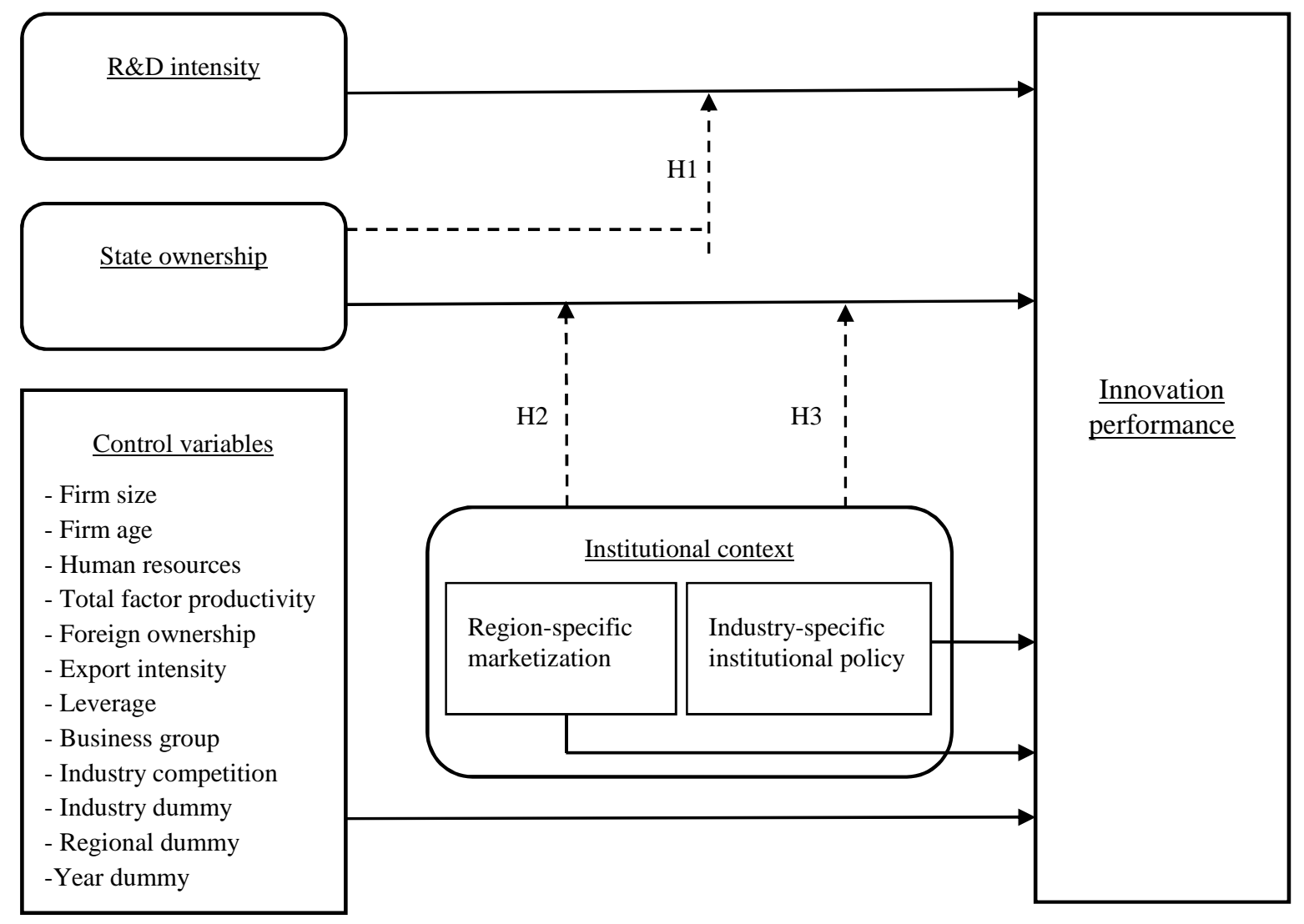

Fig. 1. Research model 


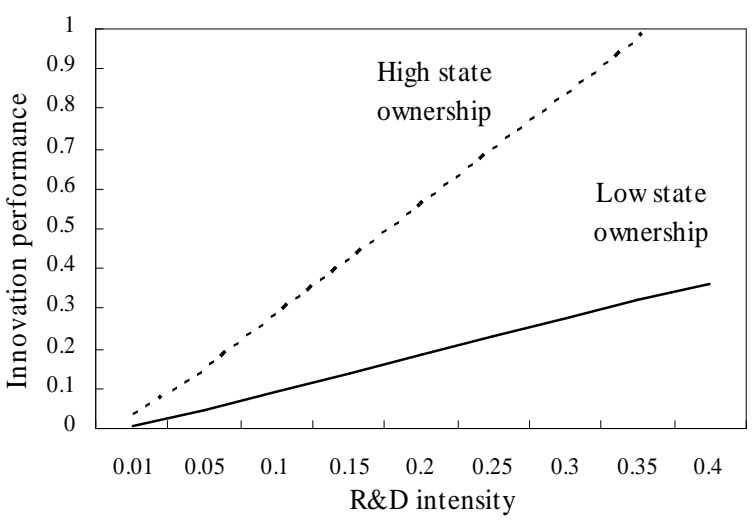

(a) Moderating role of state ownership

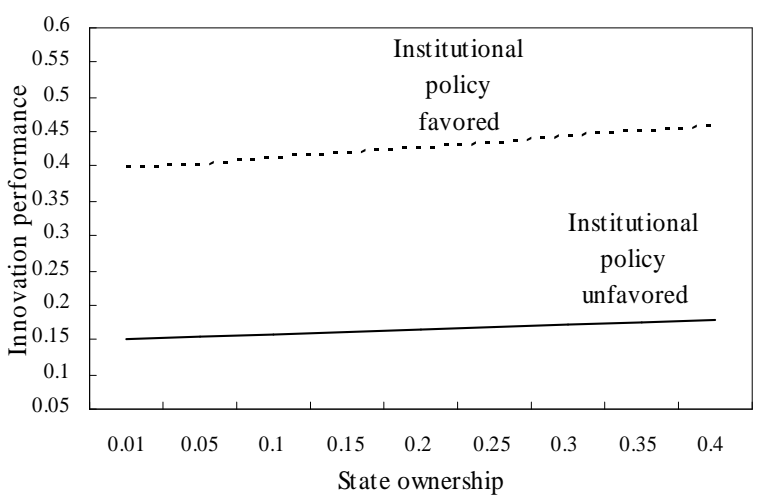

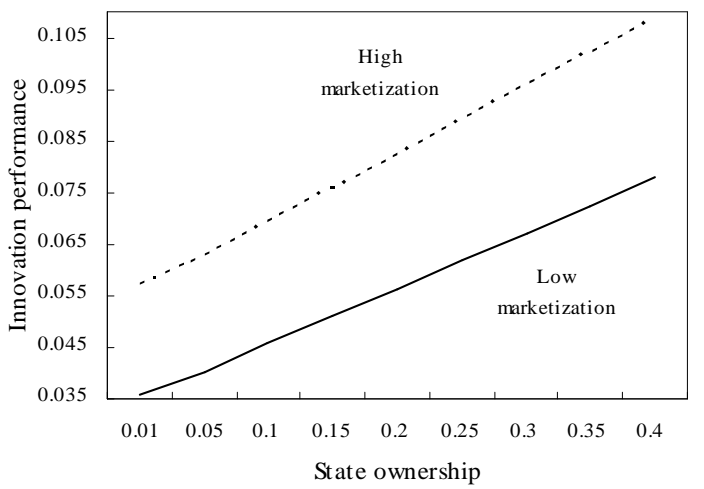

(b) Moderating role of region-specific marketization

(c) Moderating role of industry-specific institutional policy

Fig. 2. Moderating effects 
Table 1

Definition of variables

$$
\text { Definition }
$$

Dependent variable

Innovation performance

Independent variables

R\&D intensity

State ownership

Region-specific marketization

Industry-specific institutional policy

\section{Control variables}

\section{Firm size}

Firm age

Human resources

Total factor productivity

Foreign ownership

Export intensity

Leverage

Business group

Industry competition

Industry dummy

Region dummy

Year dummy
Ratio of new product sales to total sales

Ratio of R\&D expenditures to total sales

Ratio of state-owned assets to total assets

Region-specific marketization index by Fan et al. (2010)

Dummy, equals to 1 if affiliated to a high-tech industry supported by the government +

$\log$ (number of employees)

Number of years since establishment

Training expenditure per employee

Firm-specific total factor productivity proposed by Levinsohn and Petrin (2003)

Foreign capital share in foreign invested enterprises

Ratio of export sales to total sales

Ratio of total debts to total assets

Dummy, equals to 1 if affiliated with a business group and 0 otherwise

One minus the average Lerner's index of individual firms in the 2-digit industry

Dummy, equals to 1 if affiliated at the corresponding two-digit industry

Dummy, equals to 1 if located at the corresponding province-level region

Dummy, equals to 1 if associated with the corresponding year 
Table 2

Descriptive statistics and correlation matrix of variables

\begin{tabular}{|c|c|c|c|c|c|c|c|c|c|c|c|c|c|c|c|c|}
\hline & \multirow[t]{2}{*}{ Mean } & \multirow{2}{*}{$\begin{array}{l}\text { Standard } \\
\text { deviation }\end{array}$} & & & & & & & & & & & & & & \\
\hline & & & 1 & 2 & 3 & 4 & 5 & 6 & 7 & 8 & 9 & 10 & 11 & 12 & 13 & 14 \\
\hline 1 Innovation performance & 0.029 & 0.130 & 1.00 & & & & & & & & & & & & & \\
\hline $2 \mathrm{R} \& \mathrm{D}$ intensity & 0.002 & 0.053 & 0.06 & 1.00 & & & & & & & & & & & & \\
\hline 3State ownership & 0.029 & 0.158 & 0.03 & 0.01 & 1.00 & & & & & & & & & & & \\
\hline 4 Region-specific marketization & 9.083 & 1.708 & 0.03 & 0.00 & -0.14 & 1.00 & & & & & & & & & & \\
\hline 5 Industry-specific institutional policy & 0.068 & 0.252 & 0.10 & 0.05 & 0.02 & 0.02 & 1.00 & & & & & & & & & \\
\hline 6 Firm size & 4.763 & 1.028 & 0.09 & 0.01 & 0.10 & -0.04 & 0.08 & 1.00 & & & & & & & & \\
\hline 7 Firm age & 8.941 & 9.009 & 0.05 & 0.01 & 0.28 & -0.04 & 0.02 & 0.20 & 1.00 & & & & & & & \\
\hline 8 Human resources & 0.136 & 0.695 & 0.03 & 0.02 & 0.02 & -0.00 & 0.03 & -0.03 & 0.01 & 1.00 & & & & & & \\
\hline 9 Total factor productivity & 10.101 & 1.098 & 0.09 & -0.00 & 0.03 & -0.02 & 0.05 & 0.57 & 0.08 & 0.06 & 1.00 & & & & & \\
\hline 10 Foreign ownership & 0.088 & 0.266 & 0.00 & 0.00 & -0.04 & 0.11 & 0.08 & 0.11 & -0.06 & 0.01 & 0.13 & 1.00 & & & & \\
\hline 11 Export intensity & 0.188 & 0.352 & 0.04 & -0.01 & -0.07 & 0.25 & 0.03 & 0.25 & -0.03 & -0.03 & 0.05 & 0.26 & 1.00 & & & \\
\hline 12 Leverage & 0.563 & 0.295 & -0.00 & -0.00 & 0.08 & 0.05 & -0.02 & 0.05 & 0.09 & -0.01 & -0.03 & -0.07 & -0.01 & 1.00 & & \\
\hline 13 Business group & 0.028 & 0.165 & 0.05 & 0.01 & 0.09 & -0.02 & 0.00 & 0.13 & 0.13 & 0.01 & 0.07 & -0.02 & -0.01 & 0.04 & 1.00 & \\
\hline 14 Industry competition & 0.968 & 0.029 & 0.02 & 0.02 & 0.00 & 0.03 & 0.08 & 0.02 & 0.01 & 0.01 & 0.04 & 0.01 & -0.01 & 0.01 & 0.00 & 1.00 \\
\hline
\end{tabular}

Note: All the correlation coefficients are statistically different from zero at the $1 \%$ significance level. 
Table 3

Hierarchical moderated regression of innovation performance 2005-2007: Tobit estimation

\begin{tabular}{|c|c|c|c|c|c|c|}
\hline & Model 1 & Model 2 & Model 3 & Model 4 & Model 5 & Model 6 \\
\hline \multicolumn{7}{|l|}{ Independent variables } \\
\hline R\&D intensity & & $0.811 * * *$ & $0.879 * * *$ & $0.811 * * *$ & $0.811 * * *$ & $0.876^{* * *}$ \\
\hline State ownership & & $0.094 * * *$ & $0.079 * * *$ & $0.108 * * *$ & $0.082 * * *$ & $0.084 * * *$ \\
\hline Region-specific marketization & & $0.209 * * *$ & $0.209 * * *$ & $0.208 * * *$ & $0.209 * * *$ & $0.208 * * *$ \\
\hline Industry-specific institutional policy & & $0.212 * * *$ & $0.211 * * *$ & $0.211 * * *$ & $0.210 * * *$ & $0.209 * * *$ \\
\hline \multicolumn{7}{|l|}{ Interactions } \\
\hline R\&D intensity $\times$ State ownership (H1) & & & $1.835 * * *$ & & & $1.756 * * *$ \\
\hline State ownership $\times$ Region-specific marketization $(\mathrm{H} 2)$ & & & & $0.015 * *$ & & $0.013 * *$ \\
\hline State ownership $\times$ Industry-specific institutional policy (H3) & & & & & $0.083 * * *$ & $0.057 * *$ \\
\hline \multicolumn{7}{|l|}{ Control variables } \\
\hline Firm size & $0.068 * * *$ & $0.065^{* * *}$ & $0.064 * * *$ & $0.065 * * *$ & $0.065 * * *$ & $0.065 * * *$ \\
\hline Firm age & $0.005 * * *$ & $0.004 * * *$ & $0.004 * * *$ & $0.004 * * *$ & $0.004 * * *$ & $0.004 * * *$ \\
\hline Human resources & $0.025 * * *$ & $0.023 * * *$ & $0.023 * * *$ & $0.023 * * *$ & $0.022 * * *$ & $0.022 * * *$ \\
\hline Total factor productivity & $0.104 * * *$ & $0.106^{* * * *}$ & $0.106 * * *$ & $0.106 * * *$ & $0.106 * * *$ & $0.106 * * *$ \\
\hline Foreign ownership & $-0.075^{* * *}$ & $-0.074 * * *$ & $-0.074 * * *$ & $-0.073 * * *$ & $-0.074 * * *$ & $-0.073 * * *$ \\
\hline Export intensity & $0.076 * * *$ & $0.081 * * *$ & $0.081 * * *$ & $0.081 * * *$ & $0.081 * * *$ & $0.081 * * *$ \\
\hline Leverage & $-0.079 * * *$ & $-0.080 * * *$ & $-0.079 * * *$ & $-0.079 * * *$ & $-0.079 * * *$ & $-0.078 * * *$ \\
\hline Business group & $0.094 * * *$ & $0.087 * * *$ & $0.086 * * *$ & $0.087 * * *$ & $0.086 * * *$ & $0.087 * * *$ \\
\hline Industry competition & $-1.071 * * *$ & $-1.308 * * *$ & $-1.304 * * *$ & $-1.307 * * *$ & $-1.299 * * *$ & $-1.297 * * *$ \\
\hline Industry dummies & Yes & Yes & Yes & Yes & Yes & Yes \\
\hline Region dummies & Yes & Yes & Yes & Yes & Yes & Yes \\
\hline Year dummies & Yes & Yes & Yes & Yes & Yes & Yes \\
\hline Sample size & 386,334 & 386,210 & 386,210 & 386,210 & 386,210 & 386,210 \\
\hline Log likelihood & -98845.29 & -98348.18 & -98324.62 & -98345.61 & -98344.20 & -98320.62 \\
\hline$\chi^{2 \text {-statistic }}$ & $36082.27 * * *$ & $37031.02 * * *$ & $37078.13 * * *$ & $37036.15 * * *$ & $37038.98 * * *$ & $37086.13 * * *$ \\
\hline Pseudo $\mathrm{R}^{2}$ & 0.154 & 0.157 & 0.158 & 0.158 & 0.158 & 0.159 \\
\hline
\end{tabular}

Note: ${ }^{*} p<0.10, * * p<0.05, * * * p<0.01$. 
Table 4

Robustness analyses

\begin{tabular}{|c|c|c|c|c|c|c|}
\hline & \multicolumn{3}{|c|}{$\underline{\text { OLS }}$} & \multicolumn{3}{|c|}{ Two-step GMM IV } \\
\hline & Model 3 & Model 4 & Model 5 & Model 3 & Model 4 & Model 5 \\
\hline \multicolumn{7}{|l|}{ Independent variables } \\
\hline $\mathrm{R} \& \mathrm{D}$ intensity & $0.326 * *$ & $0.305 *$ & $0.305^{*}$ & $0.816 * * *$ & $0.677 * * *$ & $0.822 * * *$ \\
\hline State ownership & $0.007 * * *$ & $0.013 * * *$ & $0.006^{* * *}$ & $0.098 * * *$ & $0.146 * * *$ & $0.097 * * *$ \\
\hline Region-specific marketization & $0.011 * * *$ & $0.011 * * *$ & $0.011 * * *$ & $0.012 * * *$ & $0.011 * * *$ & $0.012 * * *$ \\
\hline Industry-specific institutional policy & $0.035 * * *$ & $0.035 * * *$ & $0.035 * * *$ & $0.028 * * *$ & $0.029 * * *$ & $0.029 * * *$ \\
\hline \multicolumn{7}{|l|}{ Interactions } \\
\hline R\&D intensity $\times$ State ownership $(\mathrm{H} 1)$ & $0.600 * *$ & & & $3.310 * *$ & & \\
\hline State ownership $\times$ Region-specific marketization $(\mathrm{H} 2)$ & & $0.003 * * *$ & & & $0.035 * * *$ & \\
\hline State ownership $\times$ Industry-specific institutional policy $(\mathrm{H} 3)$ & & & $0.037 * * *$ & & & $0.132 * * *$ \\
\hline Sample size & 386,210 & 386,210 & 386,210 & 386,210 & 386,210 & 386,210 \\
\hline F-statistic & $186.70 * * *$ & $186.71 * * *$ & $186.80 * * *$ & $185.60 * * *$ & $187.33 * * *$ & $186.17 * * *$ \\
\hline Adjusted $\mathrm{R}^{2}$ & 0.071 & 0.071 & 0.071 & -- & -- & -- \\
\hline Endogeneity test & -- & -- & -- & $274.86 * * *$ & $256.45 * * *$ & $260.46 * * *$ \\
\hline Instrument redundancy test & -- & -- & -- & $4022.87 * * *$ & $3289.02 * * *$ & $4022.47 * * *$ \\
\hline
\end{tabular}

Note: $* \mathrm{p}<0.10, * * \mathrm{p}<0.05, * * * \mathrm{p}<0.01$. Control variables are excluded to save space. 